\title{
Strawberry monocropping: Impacts on fruit yield and soil microorganisms
}

\author{
Nadia C. Lovaisa ${ }^{1 \dagger}$, María F. Guerrero-Molina ${ }^{1 \dagger}$, Paola G. Delaporte-Quintana ${ }^{1}$, Mara D. \\ Alderete $^{1}$, Alicia L. Ragout ${ }^{2}$, Sergio M. Salazar ${ }^{1,3}$, Raúl O. Pedraza ${ }^{1 *}$
}

${ }^{1}$ Universidad Nacional de Tucumán, Facultad de Agronomía y Zootecnia. Av. Kirchner 1900. CP 4000 San Miguel de Tucumán. Tucumán, Argentina. ${ }^{2}$ PROIMI-CONICET. Av. Belgrano y Pje. Caseros. CP 4000 San Miguel de Tucumán. Tucumán, Argentina. ${ }^{3}$ Instituto Nacional de Tecnología Agropecuaria (INTA), Estación Experimental Agrícola (EEA) Famaillá. Ruta Provincial $301 \mathrm{~km}$ 32. CP 4132. Famaillá, Tucumán, Argentina. ${ }^{*}$ Corresponding author: raulpedraza03@yahoo.com.ar Both authors contributed equally to this work.

\begin{abstract}
The objective of this work was to explore the impacts of intensive strawberry monocropping during five years on the fruit-yield and on the microbial soil activity and composition. Field trials were performed in two plots: P1(a soil with five years of consecutive strawberry cropping), and P2 (a soil with just one year of strawberry cropping). Fruit-yield was quantified; total microorganisms and four functional groups (cellulolytics, nitrogen-fixers, phosphate solubilizers, and siderophores producers) were quantified, isolated and characterized in both plots. Total microbial activity was assessed by the hydrolysis of fluorescein-diacetate and soil respiration methods. As results, in P1, a $51 \%$ decrease in fruit-yield was observed, while in P2 it was closer to the yield obtained in P1 during the first and second year of cultivation. Total microbial number and activity were $23 \%$ and $70 \%$ lower in P1 than in P2 at the end of the cropping, respectively. In general, the quantity of total culturable microorganisms and the functional groups analyzed were significantly higher in P2 than in P1 $(p<0.05)$. The most prevailing bacteria putatively identified were Cellulosimicrobium cellulans, Paenibacillus sp., Azospirillum brasilense, and Burkholderia sp. According to our results, the intensive cultivation of strawberry for several years in the same field exerted a negative impact on the soil quality, affecting the native microbial population, which might be linked to the fruit yield decline.
\end{abstract}

Keywords: Fragaria ananassa, soil quality, monocropping, soil microbiota 


\section{Introduction}

Monocropping is the agronomic practice of growing a single crop year after year on the same land, in the absence of rotation with other crops or growing multiple crops on the same land. Several studies have indicated that consecutive monocropping can lead to crop yield and soil quality decline and increased disease pressure (Li et al., 2012). This was observed in different crops such as tomato (Seliga and Shattuch, 1995), pomegranate (Sharma et al., 2015), cucumber (Wu and Wang, 2007), potato, peanut (Liu et al., 2015), and recently in a study on soil microbial diversity and activity linked to crop yield and quality in a dryland organic wheat production system (Tautges et al., 2016).

The quality of a soil is inferred from measurable soil properties, known as soil quality indicators, including traditional measures such as chemical, physical and biological properties (Mäder et al., 2002). Soil microorganisms are vital to agroecosystem function and sustainability, but are sensitive to changes in land management practices, such as cropping system, tillage and fertilization (Zhou et al., 2014). Consequently, soil microbial parameters such as microbial composition and diversity have been suggested as possible indicators of soil quality and soil function. The methods usually employed to measure the biological properties of the soil are: the quantification of microbial biomass, activity and diversity, analysis of community structure and plant-microbe interactions; soil DNA analysis using microarray and 16S rRNA gene pyrosequencing technologies (Benedetti and Dilly, 2006; Liu et al., 2015). However, little is known about the impacts of intensive strawberry monocropping on crop productivity and soil native microbiota.

Strawberry is a fruit crop with high economic value with an annual worldwide production estimated of around 4,500,000 t (FAOSTAT, 2014, http://fostat.fao. org). In all the producing countries around the world, it is generally performed as an intensive crop with high input of agrochemicals (fertilizers, pesticides, etc.), which, despite contributing to the success of the crop, may have an adverse impact on the environment. In general, the current production system includes annual planting, black polyethylene mulch, drip fertigation and polyethylene one-row tunnels. However, it is well known that many crops experience a decline in productivity when replanted in the same site (Bennett et al., 2012). This could be related, in part, to some deterioration of the soil quality which could also be reflected in its microbial community, generally related to those functional groups that contribute to its fertility, such as cellulolytics, nitrogen-fixers, phosphate solubilizers and siderophores producers, as well as the total microorganisms and their enzymatic activities. Considering that soil quality is related to the sustainability of biological productivity, maintenance of environmental quality, and promotion of plant performance, the objective of this work was to explore the impacts of intensive strawberry monocropping during five years on the strawberry fruit yield and on the microbial soil activity and composition, considering total culturable microorganisms and some functional groups of agricultural importance.

\section{Materials and Methods}

\subsection{Site description}

The study was conducted at the Experimental Station of INTA-Famaillá, province of Tucumán, Argentina $\left(27^{\circ} 03^{\prime} \mathrm{S}, 65^{\circ} 25^{\prime} \mathrm{W}\right.$; $363 \mathrm{~m}$ above sea level). The climate is subtropical sub-humid. According to the US Soil Taxonomy System, the soil is an Aquic Argiudoll. The field was divided into two plots: P1, soil subjected to 5 consecutive years of strawberry 
cropping from 2006 till 2010, and P2, soil first implanted with strawberry in 2010. Before the assays, P1 and P2 were not cultivated, neither fertilized nor tilled; they were just covered with different weeds which were then mechanically removed before planting strawberry.

\subsection{Strawberry cropping}

Strawberry plants (Fragaria ananassa Duch.) cultivar Camarosa were purchased from commercial nurseries at San Carlos, Mendoza, Argentina. Before planting, raised beds were formed each year and covered with black polyethylene to prevent weed growth and erosion. Each experimental plot (P1 and P2) had 80 embankments of $100 \mathrm{~m}$ long. Cropping beds consisted of raised beds $1.25 \mathrm{~m}$ apart, $0.40 \mathrm{~m}$ high, $0.50 \mathrm{~m}$ wide, with two rows of plants. A rate of $200 \mathrm{~kg} / \mathrm{ha}$ of N, P, K (15-15-15) fertilizer was applied as pre-planting fertilizer every year. The experimental design to evaluate fruit-yield was a randomized complete block with 30 plants each. Fruit was harvested from July to November, two or three times a week, according to its maturity. Total yield per year was measured $(\mathrm{kg} / \mathrm{ha})$ and subjected to t-test for independent samples at 5 $\%$ of significance level by using the Statistix Analytical Software 1996 for Windows ${ }^{\circledR}$. At the end of every harvest season, the plastic was removed and the plants were plowed into the ground.

\subsection{Sampling of soil to assess its microbiological status}

Soil samples were taken from P1 and P2. The samples of each plot were taken from three subplots separated $5 \mathrm{~m}$ from each other, in order to avoid any heterogeneity effect of the soil, in the following months: May (crop planting); July (beginning of fruit production); September (maximum fruit production); and November (completion of the fruit production cycle). In the
Southern hemisphere this signifies taking soil samples in autumn (May), winter (July), and spring (September, November). The average rainfall and temperatures during these months were: $25 \mathrm{~mm}$ and $17^{\circ} \mathrm{C}$ in May; $20 \mathrm{~mm}$ and $12{ }^{\circ} \mathrm{C}$ in July; $40 \mathrm{~mm}$ and $19^{\circ} \mathrm{C}$ in September; $110 \mathrm{~mm}$ and $25^{\circ} \mathrm{C}$ in November (data recorded in the meteorological station at INTA-Famaillá).

For each sampling period, three completely randomized soil samples were collected from each subplot. The samples were composites of 9 subsamples of 1 $\mathrm{kg}$ each taken with an auger (down to a depth of 30 $\mathrm{cm}$ ) from the middle of embankments planted with strawberries. The subsamples of soil were placed in labeled plastic bags and immediately taken to the laboratory where they were homogenized and sieved. Table 1 shows the physical and chemical characteristics of the soil analyzed at the beginning (P1, year 2006) and at the end of the production cycle (P1 and P2, year 2010). Data obtained from the Laboratory $\mathrm{pH} 7$, Tucumán, Argentina (the organic matter was determined with Walkley and Black method; the oxidable carbon value corresponds to the determination of the oxidizable carbon produced by potassium dichromate in a medium of sulfuric acid (heat) through its titration with $0.5 \mathrm{~N}$ Mohr salt. The nitrogen content was determined by Kjeldahl method, and the extractable phosphorous by Bray and Kurtz method.

\subsection{Quantification of microorganisms}

From each composite-soil sample decimal serial dilutions were performed to quantify total culturable microorganisms and four functional groups of agricultural importance, starting with $10 \mathrm{~g}$ of soil dissolved in $90 \mathrm{~mL}$ of $1 \mathrm{M}$ potassium phosphate buffer, $\mathrm{pH}$ 7.0. To quantify soil microorganisms $100 \mu \mathrm{L}$ of each dilution were plated by triplicate in different growth culture media (solid or semi-solid, indicated below). In all cases, the incubation was at $30^{\circ} \mathrm{C}$ for $48-72 \mathrm{~h}$. 
Table 1. Physical and chemical characteristics of the soil (Aquic Argiudoll) considering two plots: P1, analyzed at the beginning of the trial in 2006 and after 5 consecutive years of intensive cultivation of strawberry (2010), and P2 first time cultivated with strawberry (2010)

\begin{tabular}{llll}
\hline Year & $\mathbf{2 0 0 6}$ & $\mathbf{2 0 1 0}$ & \\
\hline & $\mathbf{P 1}$ & $\mathbf{P 1}$ & $\mathbf{P 2}$ \\
$\mathbf{p H}$ & 5.3 & 5.5 & 6.5 \\
OM (\%) & 2.62 & 2 & 2.5 \\
Cox (\%) & 1.6 & 1.15 & 1.45 \\
$\mathbf{N}(\mathbf{p p m})$ & 0.15 & 0.09 & 0.11 \\
$\mathbf{P}(\mathbf{p p m})$ & 31.6 & 39 & 35 \\
Texture & Silt Loam & Silt Loam & Silt Loam \\
EC (dS/m) & 0.79 & 0.85 & 0.85 \\
\hline
\end{tabular}

OM: Organic Matter; Cox: Oxidable Carbon; N: Nitrogen; P: Phosphorous; EC: Electric Conductivity.

\subsubsection{Total microorganisms}

Nutrient agar medium (meat extract $3 \mathrm{~g} / \mathrm{L}$; casein peptone $5 \mathrm{~g} / \mathrm{L} ; \mathrm{NaCl} 5 \mathrm{~g} / \mathrm{L}$; agar $20 \mathrm{~g} / \mathrm{L} ; \mathrm{pH}$ 7.2) was used to determine the total number of culturable microorganisms.

\subsubsection{Cellulolytics}

Nutrient agar culture medium supplemented with carboxymethylcellulose $1 \%(\mathrm{w} / \mathrm{v})$ was used to isolate cellulolytics; to differentiate fungi and bacteria this medium was added with tetracycline (Tc) $5 \mu \mathrm{g} /$ $\mathrm{mL}$ and chloramphenicol (Cf) $5 \mu \mathrm{g} / \mathrm{mL}$, or with the fungicide carbendazim $(0.25 \mu \mathrm{g} / \mathrm{mL})$. The presence of cellulolytics was observed by staining the plates with Congo Red, according to Teather and Wood (1982).

\subsubsection{Nitrogen fixers}

To determine nitrogen-fixing bacteria Ashby and $\mathrm{NFb}$ media were used (Subba Rao, 1977; Baldani and Döbereiner, 1980). Ashby composition was: Mannitol $5 \mathrm{~g} / \mathrm{L}, \mathrm{KH}_{2} \mathrm{PO}_{4} 0.2 \mathrm{~g} / \mathrm{L}, \mathrm{MgSO}_{4} .7 \mathrm{H}_{2} \mathrm{O} 0.2 \mathrm{~g} / \mathrm{L}, \mathrm{NaCl}$
$0.2 \mathrm{~g} / \mathrm{L}, \mathrm{CaSO}_{4} 1 \mathrm{~g} / \mathrm{L}, \mathrm{CaCO}_{3} 5 \mathrm{~g} / \mathrm{L}$, agar $20 \mathrm{~g} / \mathrm{L}$; $\mathrm{pH}$ 7.2. The semisolid NFb medium composition was: Malic acid $5 \mathrm{~g} / \mathrm{L}, \mathrm{KH}_{2} \mathrm{PO}_{4} 0.5 \mathrm{~g} / \mathrm{L}, \mathrm{MgSO}_{4} .7 \mathrm{H}_{2} \mathrm{O} 0.2$ $\mathrm{g} / \mathrm{L}, \mathrm{NaCl} 0.2 \mathrm{~g} / \mathrm{L}, \mathrm{CaCl}_{2} .2 \mathrm{H}_{2} \mathrm{O} 0.02 \mathrm{~g} / \mathrm{L}, 2 \mathrm{~mL} / \mathrm{L}$ micronutrients solution $\left(\mathrm{CuSO}_{4} .5 \mathrm{H}_{2} \mathrm{O} 0.04 \mathrm{~g} / \mathrm{L}, 1.2\right.$ $\mathrm{g} / \mathrm{L} \mathrm{ZnSO}_{4} \cdot 7 \mathrm{H}_{2} \mathrm{O}, 1.4 \mathrm{~g} / \mathrm{L} \mathrm{H}_{3} \mathrm{BO}_{3}, 1 \mathrm{~g} / \mathrm{L} \mathrm{NaMoO}_{4} \cdot$ $\left.2 \mathrm{H}_{2} \mathrm{O}\right), 2 \mathrm{~mL} / \mathrm{L}$ bromothymol blue $(0.5 \% \mathrm{w} / \mathrm{v}$ in $0.2 \mathrm{~N}$ $\mathrm{KOH}), 4 \mathrm{~mL} / \mathrm{L}$ Fe EDTA (1.64\% w/v, aqueous), agar $1.8 \mathrm{~g} / \mathrm{L} ; \mathrm{pH} 6.8$; it was distributed in glass vials (5 $\mathrm{mL}$ ) to determine the most probable number (MPN) of diazotrophs per gram of fresh soil using the McCrady probability table for three replicates (Pedraza et al., 2007). The cultures forming a typical white pellicle below the surface of the semisolid medium were considered positive after checking the presence of bacteria by optical microscopy.

\subsubsection{Phosphate solubilizers}

The culture medium NBRIP (National Botanical Research Institute's Phosphate; Nautiyal, 1999) was used. Its composition was: Glucose $10 \mathrm{~g} / \mathrm{L}, \mathrm{Ca}_{3}\left(\mathrm{PO}_{4}\right)_{2}$ $5 \mathrm{~g} / \mathrm{L}, \mathrm{MgCl}_{2} \cdot 6 \mathrm{H}_{2} \mathrm{O} 5 \mathrm{~g} / \mathrm{L}, \mathrm{MgSO}_{4} \cdot 7 \mathrm{H}_{2} \mathrm{O} 0.25 \mathrm{~g} / \mathrm{L}$, $\mathrm{KCl} 0.2 \mathrm{~g} / \mathrm{L},\left(\mathrm{NH}_{4}\right)_{2} \mathrm{SO}_{4} 0.1 \mathrm{~g} / \mathrm{L}$, agar $17 \mathrm{~g} / \mathrm{L} ; \mathrm{pH}$ 7.0. 
The presence of clear halos around the colonies was considered as a positive result for the presence of phosphate solubilizers.

\subsubsection{Siderophores producers}

The solid culture medium NFb-Chrome Azurol Sulfonate (Sigma) was prepared as described by Tortora et al. (2011). The presence of yellow-orange halos around the colonies was considered as a positive siderophores production.

In all these determinations, results were subjected to t-test at $5 \%$ of significance level for independent samples within each month-functional group-soil combination with the Statistix Analytical Software 1996 for Windows ${ }^{\circledR}$. To compare the simultaneous effect of the different functional groups in the plots, a Principal Component Analysis (PCA) was performed by using the R statistic software (RStudio Team, 2015; http:// www.rstudio.com). To identify the Principal Components, Kaiser's stopping rule and Scree test along with the $\%$ of variance were used. Also, to identify variables of each principal component the broken-stick model was applied. Interpretation and evaluation of the PCA was plotted in the variables factor map and individuals factor map by using the FactoMiner package in R statistic software.

\subsection{Characterization of microbial isolates}

Pure isolates of each functional group were obtained from P1 and P2 and characterized macroscopically to determine type, color and shape of the isolated colonies. Their microscopic features were analyzed by mounting fresh cultures of the isolates on slides to observe their morphology, size, motility, and clustering using a Leica microscope DM500 (40X and 100X). Also, they were Gram stained. Subsequently, a representative isolate of each group was characterized by
16S rDNA sequencing and ultrastructure analysis using scanning electron microscopy (SEM).

\subsubsection{S rDNA-sequencing}

A fragment of the $16 \mathrm{~S}$ rDNA gene $(1,450 \mathrm{bp})$ was amplified with the universal primers $27 \mathrm{f}$ ( $5^{\prime}$-GAGAGTTTGATCCTGGCTCAG) and 1492r (5'-CTACGGCTACCTTGTTACGA, and the conditions prescribed by Grifoni et al. (1995). Then, the amplified products were purified and sequenced with the 4-capillary ABI 3130/Hitachi Genetic Analyzer (Applied Biosystems, USA) using the same primers. Sequence analysis was performed using nucleotide sequences available in the GenBank, EMBL, DDBJ and PDB databases of the National Center for Biotechnology Information (NCBI).

\subsubsection{Scanning electron microscopy}

Pure cultures of representative isolates of each functional group were fixed and processed for SEM according to Guerrero-Molina et al. (2012) and examined with a ZEISS SUPRA 55VP (Carl Zeiss Co., Germany) scanning electron microscope.

\subsubsection{PCR-amplification of nif $\mathrm{D}$ gene}

The potential $\mathrm{N}_{2}$ fixing capacity of isolates from $\mathrm{N}$ free media ( $\mathrm{NFb}$ and Ashby) was assessed at least three times by PCR-amplification of a $\sim 710$ bp fragment of the nif $\mathrm{D}$ gene using the primers and conditions described by Potrich et al. (2001): nifD-up (5'ATCATCGGTGACTACAAC) and nifD-do (5'ATCCATGTCGCGGCGAA). DNA of the $\mathrm{N}_{2}$-fixing bacterium Azospirillum brasilense Sp7 (ATCC 29145) was used as positive control. The amplified products were analyzed by electrophoresis in agarose gel $1 \%(\mathrm{w} / \mathrm{v})$. 


\subsection{Total microbial activity of the soil}

Two methodologies were used to measure total microbial activity:

\subsubsection{Enzymatic activity}

Estimation of the enzymatic activity by spectroscopic quantification of fluorescein produced by hydrolysis of the substrate fluorescein-diacetate (FDA) by the action of proteases, lipases, and esterases, according to Margesin (2005). For this, $1 \mathrm{~g}$ soil sample was mixed with $15 \mathrm{~mL}$ of $60 \mathrm{mM}$ potassium phosphate buffer ( $\mathrm{pH}$ 7.6) and $0.1 \mathrm{~mL}$ of FDA solution $(1 \mathrm{mg} / \mathrm{mL})$ for $2 \mathrm{~h}$ at $25^{\circ} \mathrm{C}$ (100 rpm). Then $10 \mathrm{~mL}$ of acetone was added, shaken and filtrated. Absorbance was measured at $490 \mathrm{~nm}$.

\subsubsection{Soil respiration}

Determination of the soil respiration by quantifying $\mathrm{CO}_{2}$ produced per $10 \mathrm{~g}$ of fresh soil per day according to the protocol described by Anderson (1982). This indicates the magnitude of the microbial activity and represents the $\mathrm{CO}_{2}$ emitted by the soil aerobic heterotrophic microflora in a ten-day incubation period under controlled humidity conditions. Here it was determined at $50 \%$ water holding capacity, and at $25^{\circ} \mathrm{C}$. The $\mathrm{CO}_{2}$ captured in $0.1 \mathrm{M} \mathrm{NaOH}$ was titrated with $0.1 \mathrm{M} \mathrm{HCl}$, using phenolphthalein as indicator (Anderson, 1982).

\section{Results}

\subsection{Strawberry fruit-yield}

During the five years of strawberry cropping in P1, from 2006 to 2010, a decrease in fruit-yield was observed (Table 2). The average value obtained in 2010 was $51 \%$ lower than in 2006. However, the fruit-yield observed in P2 (first year implanted with strawberry in 2010) was closer to the yield obtained in $\mathrm{P} 1$ during the first and second year of cultivation with strawberry (2006 and 2007).

Table 2. Total fruit yield of cultivar Camarosa obtained in P1 (plot with 5 years of strawberry cropping) and P2 (plot with one year of strawberry cropping) during different years (2006-2010) in Famaillá, Tucumán, Argentina.

\begin{tabular}{|c|c|c|c|c|c|}
\hline \multirow[t]{2}{*}{ Plot } & \multicolumn{5}{|c|}{ Total yield $\left(\mathrm{kg} \mathrm{ha}^{-1}\right)$ in different years } \\
\hline & 2006 & 2007 & 2008 & 2009 & 2010 \\
\hline $\mathbf{P 1}$ & 52,939 a & $45,827 \mathrm{a}$ & $33,677 \mathrm{~b}$ & $23,159 \mathrm{~b}$ & $25,911 \mathrm{~b}$ \\
\hline P2 & $\mathrm{Nc}$ & $\mathrm{nc}$ & $\mathrm{nc}$ & $\mathrm{nc}$ & $48,607 \mathrm{a}$ \\
\hline
\end{tabular}

Different letters indicate significant differences at $p<0.05$. nc: not cultivated with strawberry or any other crop.

\subsection{Quantification of microorganisms}

The total number of soil culturable microorganisms, cellulolytics, nitrogen fixers, phosphate solubilizers and siderophore producers in P1 and P2 varied among the different months of sampling (May, July,
September and November) and cropping time (either one or five years of strawberry cultivation) as shown in Table 3. In general, the quantity of total culturable microorganisms and the functional groups analyzed were significantly higher in P2 than P1 $(p<0.05)$. The cellulolytics were discriminated as total, fungi 
and bacteria (Table 3 ) using a nutrient agar culture medium supplemented with carboxymethyl cellulose and specific antibiotics and fungicide. In this group, the fungal population showed differential characteristics, their colonies being pulverulent and cottony with diverse color shades like whitish, grayish, yellowish, and brown. Also, in NFb-CAS medium fungal siderophores producers were detected. In all cases, fungal growth was about $35 \%$ higher in $\mathrm{P} 2$ than $\mathrm{P} 1$.

Table 3. Values of total culturable microbiota, cellulolytics, $\mathrm{N}_{2}$-fixers, phosphate solubilizers and siderophores producers determined in P1 (plot with 5 years of strawberry cropping) and P2 (plot with one year of strawberry cropping) during different months of 2010.

\begin{tabular}{lll|ll|ll|ll}
\hline Group & May & & July & & \multicolumn{2}{l}{ September } & \multicolumn{2}{l}{ November } \\
\hline & $\mathbf{P 1}$ & $\mathbf{P 2}$ & $\mathbf{P 1}$ & $\mathbf{P 2}$ & $\mathbf{P 1}$ & $\mathbf{P 2}$ & P1 & \multicolumn{1}{|l}{$\mathbf{P 2}$} \\
\hline Total culturable microbiota & $1.410^{5} \mathrm{~b}$ & $2.610^{6} \mathrm{a}$ & $1.210^{5} \mathrm{~b}$ & $1.710^{7} \mathrm{a}$ & $1.010^{5} \mathrm{~b}$ & $1.110^{8} \mathrm{a}$ & $1.310^{6} \mathrm{~b}$ & $8.610^{8} \mathrm{a}$ \\
Cellulolytics (total) & $1.310^{5} \mathrm{~b}$ & $1.310^{6} \mathrm{a}$ & $1.210^{5} \mathrm{~b}$ & $2.310^{6} \mathrm{a}$ & $1.010^{5} \mathrm{~b}$ & $4.810^{6} \mathrm{a}$ & $1.310^{6} \mathrm{a}$ & $6.310^{6} \mathrm{a}$ \\
Cellulolytics (fungi) & $1.510^{4} \mathrm{~b}$ & $9.610^{5} \mathrm{a}$ & $1.010^{4} \mathrm{~b}$ & $1.510^{6} \mathrm{a}$ & $1.010^{4} \mathrm{~b}$ & $9.510^{5} \mathrm{a}$ & $1.010^{4} \mathrm{~b}$ & $3.110^{5} \mathrm{a}$ \\
Cellulolytics (bacteria) & $2.110^{5} \mathrm{~b}$ & $1.210^{6} \mathrm{a}$ & $1.010^{5} \mathrm{~b}$ & $2.410^{6} \mathrm{a}$ & $1.110^{5} \mathrm{~b}$ & $4.710^{6} \mathrm{a}$ & $1.110^{6} \mathrm{a}$ & $6.510^{6} \mathrm{a}$ \\
Nitrogen fixers & $1.210^{5} \mathrm{~b}$ & $1.010^{5} \mathrm{~b}$ & $1.010^{5} \mathrm{~b}$ & $2.510^{6} \mathrm{a}$ & $2.210^{5} \mathrm{~b}$ & $2.510^{6} \mathrm{a}$ & $3.510^{5} \mathrm{~b}$ & $5.810^{6} \mathrm{a}$ \\
Phosphate solubilizers & $2.210^{4} \mathrm{~b}$ & $2.310^{6} \mathrm{a}$ & $1.410^{4} \mathrm{~b}$ & $6.010^{6} \mathrm{a}$ & $3.410^{5} \mathrm{~b}$ & $8.410^{6} \mathrm{a}$ & $7.010^{5} \mathrm{~b}$ & $1.810^{7} \mathrm{a}$ \\
Siderophore producers & $1.010^{3} \mathrm{~b}$ & $1.010^{6} \mathrm{a}$ & $1.010^{3} \mathrm{~b}$ & $1.010^{6} \mathrm{a}$ & $1.010^{4} \mathrm{~b}$ & $1.310^{6} \mathrm{a}$ & $1.010^{4} \mathrm{~b}$ & $3.410^{6} \mathrm{a}$ \\
\hline
\end{tabular}

Values represent mean values of three replicates from soil samples obtained during 2010. Tukey multiple comparison test was applied. Different letters indicate significant differences between the plots (P1; P2) for each microbial group and months of sampling at $p<0.05$.

The principal component analysis (PCA) showed that, following Kaiser's stopping rule and Scree test, the first principal component (dimension 1) explained $81.57 \%$ of the total variability and the second principal component (dimension 2) explained 15.97\%. The broken-stick model applied considered variables with equal or greater values than $2 / 3$ of the highest variable value within each principal component. Therefore, dimension 1 included cellulolytic bacteria, total cellulolytic, nitrogen fixers, phosphate solubilizers, siderophores producers and total culturable microorganisms. Dimension 2 included only cellulolytic fungi. According to the variables factor map (Figure 1a), variables involved in dimension 1 increased towards the positive values of the $\mathrm{X}$ axis, while the cellulolytic fungi increased with the positive values of the $\mathrm{Y}$ axis, as indicated by their vectors (lines). Comparing simultaneously through PCA the different functional groups during the months of assessment (May, July, September and November), a clear distribution of individuals belonging to Plot 1 was shown, forming a group, while those corresponding to Plot 2 showed a dispersion according to the individuals factor map (Figure 1b). This was plotted 
from PCA according to the coordinates of the variables by using FactoMiner package of $\mathrm{R}$ statistic software, and the groups were formed by the proximity between individuals. Plot 1 group had lower values in all functional groups, while Plot 2 had high cellulolytic fungi values, and low to medium values in the other physiological groups for May, July and September. However, Plot 2 had low cellulolytic values, as well as Plot 1 group, and high values in the rest of the functional groups during November.
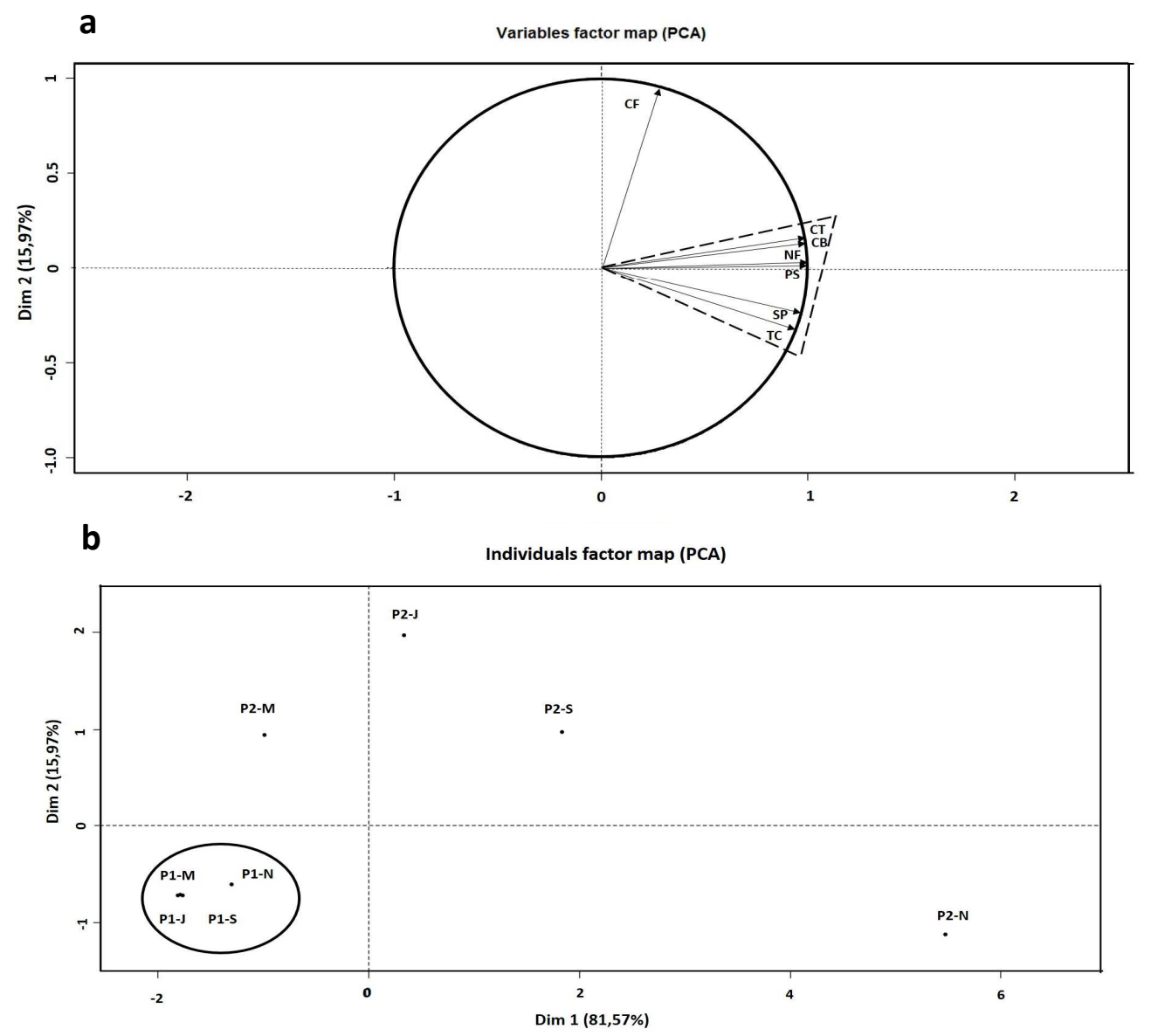

Figure 1. (a) Principal component analysis (PCA) of the different physiological groups and total microorganisms assessed in two plots (P1, after 5 years of continuous strawberry cropping, and P2, with one year of strawberry cropping), according to the variables factor map. CF: Cellulolytic fungi; CB: Cellulolytic bacteria; CT: Cellulolytic total; NF: Nitrogen fixers; PS: Phosphate solubilizers; SP: Siderophores producers; TC: Total culturable microorganisms. (b) Simultaneous PCA of the different physiological groups $\left(\mathrm{N}_{2}\right.$-fixers, phosphate solubilizers and siderophores producers) during the months of assessment during 2010, according to the individuals factor map. P1: Plot with 5 years of continuous strawberry cropping; P2: Plot with one year of strawberry cropping; M: May; J: July; S: September; N: November. 


\subsection{Characterization of microbial isolates}

The microbial characterization of a representative isolate from each functional group, as well as their GenBank accession numbers and ultrastructure are shown in Table 4. These isolates were chosen for being the most frequent within the bacterial population. The following bacteria were putatively identified: Cellulosimicrobium cellulans (cellulolytic); Paenibacillus sp. (nitrogen-fixer obtained from Ashby medium); Azospirillum brasilense (nitrogen-fixer obtained from $\mathrm{NFb}$ medium); Burkholderia sp. (phosphate solubilizer) and Azospirillum brasilense (siderophores producer) (Table 4). Only the cellulolytic isolate was Gram-positive while the rest were Gram-negative. In all cases, rod-shaped cells were observed, however the colonies varied in type and color.

Table 4. Morphological and ultrastructural characteristics of representative isolates of each physiological group and its putative designation after $16 \mathrm{~S}$ rDNA sequencing.

\begin{tabular}{|c|c|c|c|c|c|c|}
\hline $\begin{array}{l}\text { Physiological } \\
\text { group }\end{array}$ & $\begin{array}{l}\text { Colony } \\
\text { type }\end{array}$ & $\begin{array}{l}\text { Cell } \\
\text { Shape }\end{array}$ & Gram & $\begin{array}{l}\text { Cell } \\
\text { measures }\end{array}$ & Genus / Species & Ultrastructure \\
\hline Cellulolytic & $\begin{array}{l}\text { Circular with } \\
\text { entire margins, } \\
\text { pulvinet and } \\
\text { orange }\end{array}$ & $\begin{array}{l}\text { Rod- } \\
\text { shaped } \\
\text { cells }\end{array}$ & $(+)$ & $\begin{array}{l}2.153 \mu \mathrm{m} \quad \mathrm{x} \\
0.599 \mu \mathrm{m}\end{array}$ & $\begin{array}{l}\text { Cellulosimicrobiu } \\
m \text { celullans } \\
\text { CMS1 } \\
\text { KJ959225* }\end{array}$ & \\
\hline $\begin{array}{l}\mathbf{N}_{2} \text { fixer } \\
\text { (from } \\
\text { Ashby) }\end{array}$ & $\begin{array}{l}\text { Slime whitish } \\
\text { with entire- } \\
\text { irregular } \\
\text { margins }\end{array}$ & $\begin{array}{l}\text { Rod- } \\
\text { shaped } \\
\text { cells }\end{array}$ & $(-)$ & $\begin{array}{l}1.80 \mu \mathrm{m} \quad \mathrm{x} \\
0.575 \mu \mathrm{m}\end{array}$ & $\begin{array}{l}\text { Paenibacillus Sp. } \\
\text { PSS3 } \\
\text { KJ959227* }\end{array}$ & \\
\hline $\begin{array}{l}\mathbf{N}_{2} \text { fixer } \\
\text { (from NFb) }\end{array}$ & $\begin{array}{l}\text { Flat and } \\
\text { circular with } \\
\text { entire margins } \\
\text { and reddish }\end{array}$ & $\begin{array}{l}\text { Rod- } \\
\text { shaped } \\
\text { cells }\end{array}$ & $(-)$ & $\begin{array}{l}1.406 \mu \mathrm{m} \quad \mathrm{x} \\
0.663 \mu \mathrm{m}\end{array}$ & $\begin{array}{l}\text { Azospirillum } \\
\text { brasilense } \\
\text { ABS7 } \\
\text { KJ959228* }\end{array}$ & \\
\hline $\begin{array}{l}\text { Phosphate } \\
\text { solubilizer }\end{array}$ & $\begin{array}{l}\text { Circular, } \\
\text { white, flat, } \\
\text { with entire } \\
\text { margins, } \\
\text { surrounded by } \\
\text { clear halos }\end{array}$ & $\begin{array}{l}\text { Rod- } \\
\text { shaped } \\
\text { cells }\end{array}$ & $(-)$ & $\begin{array}{l}1.945 \mu \mathrm{m} \quad \mathrm{x} \\
0.568 \mu \mathrm{m}\end{array}$ & $\begin{array}{l}\text { Burkholderia Sp. } \\
\text { BSS5 } \\
\text { KJ959226* }\end{array}$ & \\
\hline $\begin{array}{l}\text { Siderophores } \\
\text { producer }\end{array}$ & $\begin{array}{l}\text { Flat and } \\
\text { circular with } \\
\text { entire margins } \\
\text { surrounded by } \\
\text { orange halos }\end{array}$ & $\begin{array}{l}\text { Rod- } \\
\text { shaped } \\
\text { cells }\end{array}$ & $(-)$ & $\begin{array}{l}1.53 \mu \mathrm{m} \quad \mathrm{x} \\
0.67 \mu \mathrm{m}\end{array}$ & $\begin{array}{l}\text { Azospirillum } \\
\text { brasilense } \\
\text { ABS7 } \\
\text { KJ959228* }\end{array}$ & \\
\hline
\end{tabular}

*GenBank accession number. 


\subsection{MPN of diazotrophs and nifD gene amplification}

The MPN of diazotrophs in P1 was one order of magnitude lower than in P2 during May, July and September (Figure 2a). In all the isolates obtained from $\mathrm{NFb}$ nitrogen-free semisolid medium a fragment of about 710 bp of the gene nifD was observed (Figure 2b). However, no amplification was observed in the isolates from Ashby medium, although it was successfully cultivated at least ten times in this $\mathrm{N}$-free medium.

a

\begin{tabular}{ccccc}
\hline Samples & May & July & September & November \\
\hline P1 & $2 \pm 0.2 \times 10^{3}$ & $1.2 \pm 0.1 \times 10^{4}$ & $1.6 \pm 0.2 \times 10^{4}$ & $1.5 \pm 0.3 \times 10^{5}$ \\
P2 & $2.5 \pm 0.5 \times 10^{4}$ & $2 \pm 0.2 \times 10^{5}$ & $2.5 \pm 0.4 \times 10^{5}$ & $4.5 \pm 0.6 \times 10^{6}$ \\
\hline
\end{tabular}

b

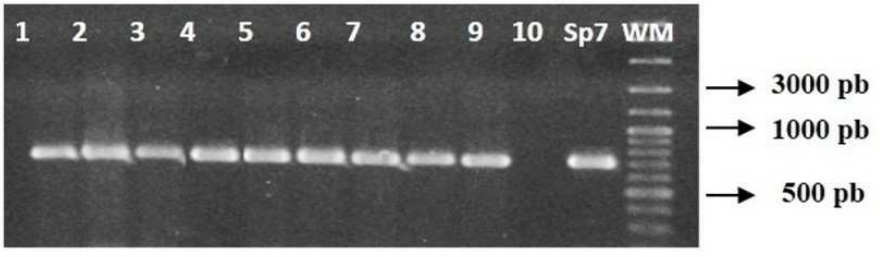

Figure 2. (a) Most Probable Number (MPN) of diazotrophs in plots P1 and P2 obtained from NFb N-free semisolid medium. The values are the average of 3 replicates and standard deviation. (b) Electrophoretic patterns of amplified 710 bp nifD fragments. The profiles correspond to isolates from NFb medium (lanes 1-9), Ashby medium (lane 10); Sp7: reference strain of Azospirillum brasilense: WM: molecular weight marker (Ladder 100 bp; Promega).

\subsection{Total microbial soil activity}

The results of total microbial activity observed in P1 and P2, evaluated by enzymatic and soil respiration methods, are shown in Figure 3. Soil enzymatic activity (expressed in $\mu \mathrm{g}$ of fluorescein/ $\mathrm{g}$ of soil/ hour) was $68.2 \%$ and $70.62 \%$ higher in $\mathrm{P} 2$ than in $\mathrm{P} 1(p<0.05)$, during September and November, respectively (Figure $3 a)$. The values correspond to the spectroscopic quantification of fluorescein produced by hydrolysis of the substrate FDA due to the action of proteases, lipases, and esterases, occurring in the native soil microorganisms, according to Margesin (2005). Similarly, soil respiration data (expressed in $\mu \mathrm{g}$ of $\mathrm{CO}_{2} / 10 \mathrm{~g}$ of soil/ day) were higher in $\mathrm{P} 2$ than in P1 for every essayed month, indicating that respiration was independent of the stage of crop production but it was greatly influenced by the amount of years with strawberry cropping when comparing P1 with P2 (Figure 3b). 
a

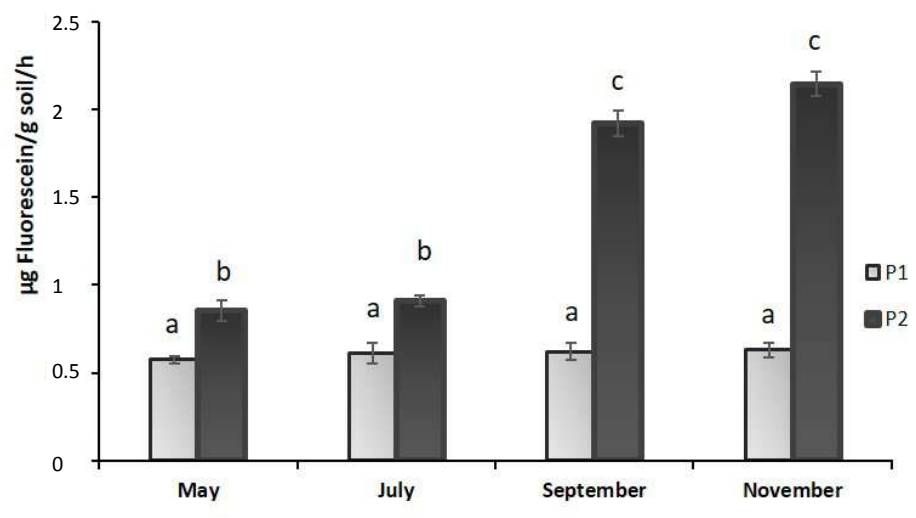

$\mathrm{b}$

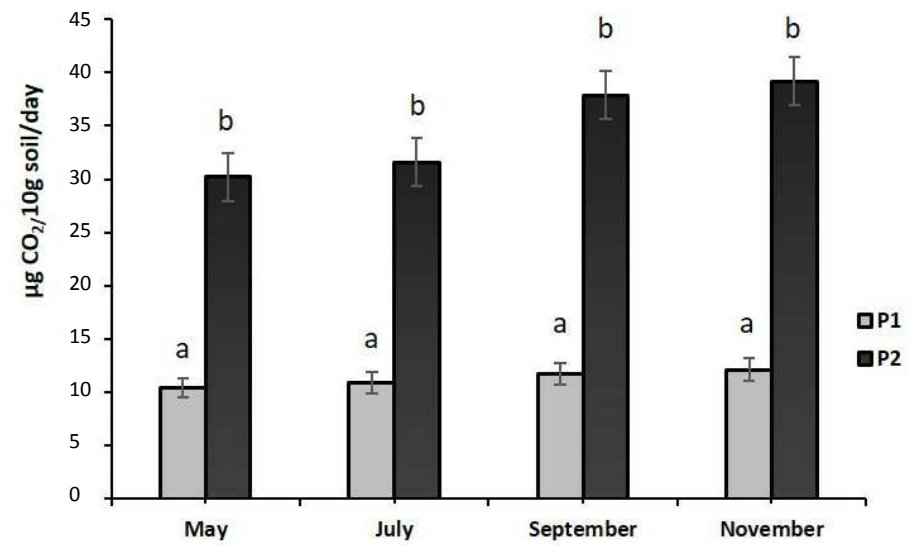

Figure 3. (a) Enzymatic activity expressed as fluorescein values resulting from the hydrolysis of fluoresceindiacetate in P1 (plot with 5 years of strawberry cropping) and P2 (plot with one year of strawberry cropping). (b) Amount of $\mathrm{CO}_{2}$ emitted by the total microbiota in P1 and P2 in different months. The values are the average of 3 replicates and its standard deviation. Different letters indicate significant differences between P1 and P2 $(p<0.05)$.

\section{Discussion}

This work was performed to explore the impacts of intensive strawberry monocropping. For that, strawberry fruit yield and soil microbiological status were assessed, comparing two situations in the same soil: one plot with five years of continuous strawberry monocropping (P1), and another one first time implanted with strawberry (P2).
It was reported that a higher soil quality may have greater microbial functional capability favoring the resilience to stressing conditions in strawberry crop (Reganold et al., 2010). In our case, the soil quality of P2 was higher than P1 (measured by its better microbiological status) and showed higher plant productivity, with fruit yields almost as good as the first year of cropping in plot P1 (yr. 2006). It is important to mention that during the five years of trial the strawberry 
plants were planted in the same period in order to avoid the effect of planting, as observed by MoshiurRahman et al. (2014) on harvest time and fruit yield. When comparing the two situations (P1 and P2), the drop in microbial number and activity over the time of intensive cropping may partially explain (from a microbiological point of view) the lower fruit yield of strawberries observed after five years of intensive cultivation in the same soil (P1). Notice that both plots were not cultivated before the assay and were just covered by weeds; therefore, although microbial number and activity were not measured before this work, this information would probably be similar for P1 and P2. There, we registered a diminution of about $10 \%$ fruit-yield after each year of cultivation, thus about $50 \%$ of decline after 5 yr. Furthermore, the lower values of $\mathrm{pH}$ and organic matter registered in P1 compared to P2, may have also negatively influenced the activity and number of soil microorganisms because they can be limiting factors of soil microbiological development. The decrease in organic matter over the years could be the underlying mechanism for the lower microbial biomass and activity in P1 compared to P2 and consequently for the lower strawberry yield. Hence, addition of organic matter could be a good strategy for enhancing strawberry yield through enhancing nutrient mineralization by microbes. Thus, it is important to stress the responsibility of the soil microorganisms status for improving the bioavailability of nutrients, considering the crucial role they play in biogeochemical cycles (Dilly, 2006).

It is known that soil microbial communities can significantly influence the productivity and overall quality of the agricultural ecosystem due to their roles in nutrient cycling, detoxification processes and soil aggregate stability, among other functions. In this study, the values of total culturable microorganism, soil enzymatic activity and respirations assessed in P2 gradually increased from May (beginning of cropping) until November (end of season), coinciding with the gradual increment of better meteorological conditions (e.g., temperature, humidity and rainfall). Meanwhile, values of soil microbial activity and respiration assessed in P1 showed a linear tendency from May to November. This indicates that these parameters were independent of the stage of crop production in P1. However, considering that those values registered in P2 (with higher organic matter content) were higher than in P1 for every month analyzed, we inferred that the quantity of microorganisms and their activities (FDA and respiration) were dependent on the amount of years of cropping in the same plot. This showed that the cultivation of strawberry during five consecutive years (without rotation with another crop) had a negative impact on the soil microbial population, and hence, it could be related to the plant productivity in that soil, although this was not demonstrated in this work. Therefore, according to Bennett et al. (2012), soil microorganisms can be implicated either directly or indirectly in the yield decline of the crops, as observed also in grasslands and maize productivity (Schnitzer et al., 2011; Bossio et al., 2005). But to support the soil microorganisms over time, the availability of organic matter is crucial. It is known that crop residues are a valuable source of organic matter for most agricultural soils; they can improve the soil quality and productivity through favorable effects on soil properties such as plant available water holding capacity, cation exchange capacity, and the stimulation of beneficial microorganisms (Saroa and Lal, 2003).

Microorganisms belonging to the cellulolytic, nitrogen-fixing, phosphate solubilizers and siderophores producers' functional groups were found in all soil samples assessed. The most prevailing native soil bacteria putatively identified in this study were Cellulosimicrobium cellulans (cellulolytic), Paenibacillus sp. ( $\mathrm{N}_{2}$-fixer), Azospirillum brasilense $\left(\mathrm{N}_{2}\right.$-fixer and siderophores producer), and Burkholderia sp. (phosphate 
solubilizer), which have importance in agriculture as they can play a role in decomposing cellulolytic material and as plant growth-promoting bacteria. About the presence of diazotrophs, confirmed by the MPN and positive nifD PCR-amplification, it was one order of magnitude higher in P2 compared with P1. Considering that the nitrogen fixing process requires a great amount of carbon substrate, the higher organic matter content in P2 compared to P1 could have probably stimulated a better development of diazotrophs in P2. It is known that the occurrence of beneficial soil organisms could suppress pathogens and diseases, improve nutrient availability, promote plant growth, and thus increase the crop yield (Yuan et al., 2014).

It was also reported that the microbial community shift can occur due to different managements of soils, impacting on their structure and functions (Schnitzer et al., 2011; Bossio et al., 2005). In this work, when analyzing the two situations: the number of total culturable microorganisms, phosphate-solubilizers, nitrogen-fixers, siderophores producers, and cellulolytics observed from May to November was higher in P2 than in P1. Besides, in the latter functional group, the fungal population was lower in P1 compared with P2 at the end of the trial. So, it was observed that the continuous cropping of strawberry in the same plot with the same management not only affected native bacteria but also fungi. These findings are consistent with reports in which total fungi and the arbuscular mycorrhizal fungi communities were found to be impoverished in species composition upon agricultural intensification, particularly upon a change from crop rotation to monocropping (Sharma et al., 2015). However, this might depend on the crop types used in the rotation and tillage. It is known that tillage (e.g., minimum, conventional or deep tillage) is one of the most important agricultural practices to ameliorate crop productivity and maintain soil health. Minimum tillage is suggested to avoid leaching losses of nutrients, thus enhancing the availability of nutrients to the plants and soil microbiota (Khan et al., 2017).

The PCA explained the variability for the different physiological groups in two dimensions, showing that the cellulolytic fungi group is important in the second principal component (dimension 2); this means that the cellulolytic fungi group was influenced by the plots and environmental conditions. Considering that at the end of every harvest season, the plastic was removed and the plants were plowed into the ground, they would be the organic substrate supporting the presence of cellulolytic fungi. Besides, their amount and activity would be also stimulated by the high temperatures and humidity occurring during the summer season, despite a different performance in $\mathrm{P} 1$ and in P2. However, the simultaneous PCA of the different physiological groups during the months of assessment showed a clear distribution in Plot 1, compared with Plot 2, according to the individuals factor map. The dispersion of values observed in P2 for May, July and September were closer than the values for November; this might be explained by the temperature and rainfall conditions. Their meteorological values increased from September to November (spring season in the Southern hemisphere) so they could have directly influenced the microbial soil activity.

According to our results, the intensive cultivation of strawberry for several years in the same field exerted a negative influence on the soil quality, affecting the native microbial population, and that could be linked to the fruit yield decline observed. Therefore, this situation should lead to another look at different alternatives of crop management, and the addition of organic matter in the form of compost, manure, or straw should specially be considered. It may well be that the decline in organic matter content (substrate limitation) was the main cause of the lower microbial biomass and activity observed in P1. The addition of compost had positive effects on the soil nutritional status, microbial 
community structure, and enzyme activity in different stages of barley cultivation (Moreno et al., 2017). Application of organic manures had significant influence on organic carbon depleted arable soils by improving maize productivity and soil physico-chemical properties (Mahmood et al., 2017). Also, residue addition frequency strongly influenced soil respiration, microbial biomass and nutrient availability after addition of low $\mathrm{C} / \mathrm{N}$ residue, for example, young faba bean (Vicia faba L.) (Zheng and Marschner, 2017).

It was reported that cover crop rotations alter soil microbiology and reduce replant disorders in strawberry (Seigies and Pritts, 2006). Furthermore, it would be possible to select preplant cover crops based on sitespecific microbiological, physical, and chemical soil properties that will considerably improve soil conditions before replanting strawberry. Also, the use of bacterial biofertilizers may enhance strawberry crop yields without adverse effects on soil properties and ensure basic criteria of sustainable fruit production (Pešaković et al., 2013). It was recently reviewed by Dane et al. (2016) the possibility of strawberry cultivation intercropping with legumes, considering that the unused soil surface between the strawberry rows is an area in which intercropping can be used. Legumes can provide nitrogen, as well as biological and physical barriers against pests and diseases (Dane et al., 2016). Consequently, more studies are needed on best agricultural practices that should be implemented in intensive cultivation of strawberry, to sustain the native soil microbiological status and avoid a possible negative impact on fruit yield.

\section{Conclusions}

The impact exerted by the intensive monocropping of strawberry in the same field during five consecutive years on fruit yield and native soil microbiota was assessed by field trials and different microbiological approaches. A decrease in fruit yield over time, and a lower microbial biomass and activity was observed in P1 compared to P2. Hence, strawberry monocropping indicates a decline of soil native microbiota over time and this could impact on plant productivity, among the different factors involved in the management of this horticultural crop.

\section{Acknowledgements}

Part of the work was supported by Secretaría de Ciencia, Arte y Tecnología, Universidad Nacional de Tucumán (Program A526). NCL, MFGM, and PGDQ are fellows of CONICET.

\section{References}

Anderson, J.P.E. 1982. Soil respiration. In: Methods of Soil Analysis, Part 2, 2nd ed., Agronomy Monograph. 9 (Eds., Page, A.L., Miller, R.H., Keeney D.R.) pp. 837-871. ASA and SSSA, Madison, WI.

Baldani, V.L.D., Döbereiner, J. 1980. Host-plant specificity in the infection of cereals with Azospirillum spp. Soil Biol. Biochem. 12, 433-439.

Benedetti, A., Dilly, O. 2006. Approaches to defining, monitoring, evaluating and managing soil quality. In: Microbiological methods for assessing soil quality (Eds., Bloem, J., Hopkins, D.W., Benedetti, A.) CAB International Publishing, London. pp. 3-14.

Bennett, A.J., Bending, G.D., Chandler, D., Hilton, S., Mills, P. 2012. Meeting the demand for crop production: the challenge of yield decline in crops grown in short rotations. Biol. Rev. 87, 52-71.

Bossio, D.A., Girvan, M.S., Verchot, L., Bullimore, J., Borelli, T., Albrecht, A., Osborn, A.M. 2005. Soil microbial community response to land use change in an agricultural landscape of western Kenya. Microb. Ecol. 49, 50-62. 
Dane, S., Laugale, V., Lepse, L., Sterne, D. 2016. Possibility of strawberry cultivation in intercropping with legumes: a review. Acta Hortic. 1137, 83-86.

Dilly, O. 2006. Ratios of microbial biomass estimates to evaluate microbial physiology in soil. Biol. Fert. Soils. 42, 241-246.

Grifoni, A., Bazzicalupo, M., Di Serio, C., Fancelli, S., Fani, R. 1995. Identification of Azospirillum strains by restriction fragment length polymorphism of the 16S rDNA and of the histidine operon. FEMS Microbiol. Lett. 127, 85-91

Guerrero-Molina, M.F., Winik, B.C., Pedraza, R.O. 2012. More than rhizosphere colonization of strawberry plants by Azospirillum brasilense. Appl. Soil Ecol. 61, 205-212.

Khan, S., Shah, A., Nawaz, M., Khan, M. 2017. Impact of different tillage practices on soil physical properties, nitrate leaching and yield attributes of maize (Zea mays L.). J. Soil Sci. Plant Nutr. 17, 240-252.

Li, P.D., Dai, C.C., Wang, X.X., Zhang, T.L., Chen, Y. 2012. Variation of soil enzyme activities and microbial community structure in peanut monocropping system in subtropical China. Afr. J. Agric. Res. 7, 1870-1879.

Liu, W., Wang Q., Wang B., Wang, X., Franks, A.E., Teng, Y., Li, Z., Luo, Y. 2015. Changes in the abundance and structure of bacterial communities under long-term fertilization treatments in a peanut monocropping system. Plant Soil. 395, 415-427.

Mäder, P., Fleissbach, A., Dubois, D., Gunst, L., Fried, P., Niggli, U. 2002. Soil fertility and biodiversity in organic farming. Science. 296, 1694-1697.

Mahmood, F., Khan, I., Ashraf, U., Shahzad, T., Hussain, S., Shahid, M., Abid, M., Ullah, S. 2017. Effects of organic and inorganic manures on maize and their residual impact on soil physico-chemical properties. J. Soil Sci. Plant Nutr. 17, 22-32.
Margesin, R. 2005. Determination of enzyme activities in contaminated soil, in: Soil Biology, Vol. 5, Manual of Soil Analysis - Monitoring and Assessing Soil Bioremediation. (Eds., Margesin, R., Schinner, F.) Springer Verlag, Berlin. pp. 309-320.

Moreno, J.L., Ondoño, S., Torres, I., Bastida, F. 2017. Compost, leonardite, and zeolite impacts on soil microbial community under barley crops. J. Soil Sci. Plant Nutr. 17, 214-230.

Moshiur-Rahman, M., Rahman, M.M., Hossain, M.M., Khaliq, Q.A., Moniruzzaman, M. 2014. Effect of planting time and genotypes growth, yield and quality of strawberry (Fragaria $\times$ ananassa Duch.). Sci. Hort. 167, 56-62.

Nautiyal, C.S. 1999. An efficient microbiological growth medium for screening phosphate solubilizing microorganisms. FEMS Microbiol. Lett. 170, 265-270.

Pedraza, R.O., Motok, J., Tortora, M.L., Salazar, S.M., Díaz-Ricci, J.C. 2007. Natural occurrence of Azospirillum brasilense in strawberry plants. Plant Soil. 295, 169-178.

Pešaković, M., Karaklajić-Stajić, Ž., Milenković, S., Mitrović, O. 2013. Biofertilizer affecting yield related characteristics of strawberry (Fragaria $\times$ ananassa Duch.) and soil micro-organisms. Sci. Hort. 150, 238-243.

Potrich, D.P., Passaglia, L.M.P. Schrank, I.S. 2001. Partial characterization of nif genes from the bacterium Azospirillum amazonense. Braz. J. Med. Biol. Res. 34, 1105-1113.

Reganold, J.P., Andrews, P.K., Reeve, J.R., Carpenter-Boggs, L., Schadt, C.W., Alldredge, J.R., Ross, C.F., Davies, N.M. and Zhou, J. 2010. Fruit and soil quality of organic and conventional strawberry agroecosystems. Public Library of Science ONE, 5, e12346. 
Saroa, G.S., Lal, R. 2003. Soil restorative effects of mulching on aggregation and carbon sequestration in a Miamian soil in Central Ohio. Land Degrad. Dev. 14, 481-493.

Schnitzer, S.A., Klironomos, J.N., Hille Ris Lambers, J., Kinkel, L.L., Reich, P.B., Xiao, K., Rillig, M.C., Sikes, B.A., Callaway, R.M., Mangan, S.A., van Nes, E.H., Scheffer, M. 2011. Soil microbes drive the classic plant diversity-productivity pattern. Ecology. 92, 296-303.

Seigies, A.T., Pritts M. 2006. Cover crop rotations alter soil microbiology and reduce replant disorders in strawberry. Hort. Sci. 41, 1303-1308.

Seliga, J.P., Shattuch, V.I. 1995. Crop rotation affects the yield and nitrogen fertilization response in processing tomatoes. Sci. Hort. 63, 159-166.

Sharma, S.D., Kumar, P., Bhardwaj, S.K., Chandel A. 2015. Agronomic performance, nutrient cycling and microbial biomass in soil as affected by pomegranate based multiple crop sequencing. Sci. Hort. 197, 504-515.

Subba Rao, N.S. 1977. Soil microorganisms and plant growth. Oxford and IBH Publishing Co., India.

Tautges, N.E., Sullivan, T.S., Catherine L. Reardon, C.L., Burke, I.C. 2016. Soil microbial diversity and activity linked to crop yield and quality in a dryland organic wheat production system. Appl. Soil Ecol. 108, 258-268.
Teather, R.M., Wood, P.J. 1982. Use of congo redpolysaccharide interactions in enumeration and characterization of cellulolytic bacteria from the bovine rumen. Appl. Environ. Microbiol. 43, 777-780.

Tortora, M.L., Díaz-Ricci, J.C., Pedraza, R.O. 2011. Azospirillum brasilense siderophores with antifungal activity against Colletotrichum acutatum. Arch. Microbiol. 193, 275-286.

Yuan, S.F., Wang, L.L., Wu, K., Shi, J.X., Wang, M.S., Yang, X.M., Shen, Q.R., Shen, B. 2014. Evaluation of Bacillus-fortified organic fertilizer for controlling tobacco bacterial wilt in greenhouse and field experiments. Appl. Soil Ecol. 75, 86-94.

Wu, F., Wang, X. 2007. Effect of monocropping and rotation on soil microbial community diversity and cucumber yield and quality under protected cultivation. Acta Hort. (ISHS). 761, 555-561.

Zheng, B., Marschner, P. 2017. Residue addition frequency influences respiration, microbial biomass and nutrient availability in soil amended with high and low $\mathrm{C} / \mathrm{N}$ residue. J. Soil Sci. Plant Nutr. 17, 1-13.

Zhou, X.G., Gao, D.M., Liu, J., Qiao, P.L., Zhou, X.L., Lu, H.B., Wu, X., Liu, D., Jin, X., Wu, F.Z. 2014. Changes in rhizosphere soil microbial communities in a continuously monocropped cucumber ( $\mathrm{Cu}$ cumis sativus L.) system. Eur. J. Soil Biol. 60, 1-8. 